\title{
Fixed point approximation of Prešić nonexpansive mappings in product of CAT (0) spaces
}

\section{HAFIZ FuKHAR-UD-DiN ${ }^{1,2}$, VASILE BERINDE ${ }^{3,1}$ and ABDUl RAHIM KHAN ${ }^{1}$}

\begin{abstract}
.
We obtain a fixed point theorem for Prešić nonexpansive mappings on the product of $C A T(0)$ spaces and approximate this fixed points through Ishikawa type iterative algorithms under relaxed conditions on the control parameters. Our results are new in the literature and are valid in uniformly convex Banach spaces.
\end{abstract}

Acknowledgements. The authors would like to acknowledge the support provided by the Deanship of Scientific Research(DSR) at King Fahd University of Petroleum \& Minerals (KFUPM) for funding this work through project No. IN151014. The second author also thanks Dr. Al-Homidan, the dean of College of Sciences, and Dr. Al-Attas, the Chairman of the Department of Mathematics and Statistics, for the excellent facilities they offered during his visit of King Fahd University of Petroleum \& Minerals (April-May 2016). The research was also supported by the CNCS-UEFISCDI project number PN-II-ID-PCE-20113-0087, ctr. No. 315.

\section{REFERENCES}

[1] Abbas, M. and Khan, S. H., Some $\triangle$-convergence theorems in $C A T(0)$ spaces, Hacet. J. Math. Stat., 40 (2011), No. 4, 563-569

[2] Berinde, V., Iterative Approximation of Fixed Points, 2nd Ed., Springer Verlag, Berlin Heidelberg New York, 2007

[3] Berinde, V., Khan, A. R. and Păcurar, M., Coupled solutions for a bivariate weakly nonexpansive operator by iterations, Fixed Point Theory Appl., 2014, 2014:149, 12 pp.

[4] Berinde, V. and Păcurar, M., An iterative method for approximating fixed points of Prešić nonexpansive mappings, Rev. Anal. Numér. Théor. Approx., 38 (2009), No. 2, 144-153

[5] Berinde, V. and Păcurar, M., A constructive approach to coupled fixed point theorems in metric spaces, Carpathian J. Math., 31 (2015), No. 3, 269-275

[6] Bestvina, M., $\mathbb{R}$-trees in topology, geometry, and group theory, Handbook of geometric topology, 55-91, NorthHolland, Amsterdam, 2002

[7] Cirić, L. B. and Prešić, S. B., On Prešić type generalization of the Banach contraction mapping principle, Acta Math. Univ. Comenian. (N.S.), 76 (2007), No. 2, 143-147

[8] Devillanova, G., Solimini, S. and Tintarev, C., On weak convergence in metric spaces, Nonlinear analysis and optimization, 43-63, Contemp. Math., 659, Amer. Math. Soc., Providence, RI, 2016

[9] Dhompongsa, S. and Panyanak, B., On $\triangle$-convergence theorems in $C A T(0)$ spaces, Comput. Math. Appl., 56 (2008), 2572-2579

[10] Espinola, R. and Kirk, W. A., Fixed point theorems in $\mathbb{R}$-trees with applications to graph theory, Topology Appl., 153 (2006), 1046-1055

Received: 12.05.2016; In revised form: 23.05.2016; Accepted: 25.05.2016

2010 Mathematics Subject Classification. 47H09, 47H10, 54H25, 47J25.

Key words and phrases. CAT (0) space, Prešić type nonexpansive mapping, fixed point, Ishikawa iterative algorithm, strong convergence.

Corresponding author: Vasile Berinde; vberinde@ubm.ro 
[11] Fukhar-ud-din, H., Existence and approximation of fixed points in convex metric spaces, Carpathian J. Math., 30 (2014), No. 2, 175-185

[12] Fukhar-ud-din, H., One step iterative scheme for a pair of nonexpansive mappings in a convex metric space, Hacet. J. Math. Stat., 44 (2015), 1023-1031

[13] Fukhar-ud-din, H. and Berinde, V., Iterative methods for the cass of quasi-contractive type operators and comparsion of their rate of convergence in convex metric spaces, Filomat, 30 (2016), No. 1, 223-230

[14] Fukhar-ud-din, H. and Saleh, K., One-step iterations for a finite family of generalized nonexpansive mappings in CAT(0) spaces, Bull. Malays. Math. Sci. Soc., (2016), DOI 10.1007/s40840-016-0310-x

[15] Ishikawa, S., Fixed points by a new iteration method, Proc. Amer. Math. Soc., 44 (1974), 147-150

[16] Khan, A. R., Fukhar-ud-din, H. and Khan, M. A. A., An implicit algorithm for two finite families of nonexpansive maps in hyperbolic spaces, Fixed Point Theory Appl., 2012, 2012:54 (doi:10.1186/1687-1812-2012-54)

[17] Kirk, W. A., Geodesic geometry and fixed point theory. II, International Conference on Fixed Point Theory and Applications, 113-142, Yokohama Publ., Yokohama, 2004

[18] Khan, A. R., Khamsi, M. A. and Fukhar-ud-din, H., Strong convergence of a general iteration scheme in CAT(0) spaces, Nonlinear Anal., 74 (2011), 783-791

[19] Khan, S. H. and Fukhar-ud-din, H., Weak and strong convergence of a scheme with errors for two nonexpansive mappings, Nonlinear Anal., 61 (2005), 1295-1301

[20] Mann, W. R., Mean value methods in iterations, Proc. Amer. Math. Soc., 4 (1953), 506-510

[21] Olaoluwa, H., Olaleru, J. O. and Chang, S.-S., Coupled fixed point theorems for asymptotically nonexpansive mappings, Fixed Point Theory Appl., 2013, 2013:68, 15 pp.

[22] Păcurar, M., Iterative Methods for Fixed Point Approximation, PhD Thesis, "Babeş-Bolyai" University, ClujNapoca, 2009

[23] Păcurar, M., A multi-step iterative method for approximating fixed points of Prešić-Kannan operators, Acta Math. Univ. Comenian. (N.S.), 79 (2010), No. 1,77-88

[24] Păcurar, M., Approximating common fixed points of Prešić-Kannan type operators by a multi-step iterative method, An. Șt. Univ. Ovidius Constanţa, 17 (2009), No. 1, 153-168

[25] Păcurar, M., A multi-step iterative method for approximating common fixed points of Prešić-Rus type operators on metric spaces, Studia Univ. Babeş-Bolyai Math., 55 (2010), No. 1, 149-162

[26] Prešić, S. B., Sur une classe d' inéquations aux différences finites et sur la convergence de certaines suites, Publ. Inst. Math. (Beograd) (N.S.), 5 (19) (1965), 75-78

[27] Rus, I. A., An iterative method for the solution of the equationx $=f(x, \ldots, x)$, Anal. Numér. Théor. Approx., 10 (1981), No. 1, 95-100

[28] Wilansky, A., Functional Analysis, First edition, Blaisedell Publishing Company, New York, Toronto, London, 1964

${ }^{1}$ Department of MATHEMATiCS AND STATistics

King Fahd University of Petroleum and Minerals

DHAHRAM, KingDOM OF SAUdi ARABIA

E-mail address: hfdin@kfupm.edu.sa; arahim@kfupm.edu.sa

${ }^{2}$ Department of Mathematics

THE ISLAMIA UNIVERSITY OF BAHAWALPUR

BAHAWALPUR 63100, PAKISTAN

${ }^{3}$ Department of Mathematics and Computer Science

North University CENTER at Baia MARE

TECHNICAL UNIVERSITY OF CLUJ-NAPOCA

VICTORIEI 76, 430122 BAIA MARE, ROMANIA

E-mail address: vberinde@ubm.ro 